\title{
Perioperative management of patients undergoing craniosynostosis repair
}

\author{
Rajni Mathur ${ }^{1}$, Tuhin Mistry ${ }^{2 *}$, Gaurav Sharma ${ }^{3}$, Vandana Mangal ${ }^{4}$ \\ Senior Professor ${ }^{1,4}$, Department of Anaesthesiology, S.M.S. Medical College, Jaipur, Rajasthan, India. \\ Post-Doctoral Fellow in Regional Anaesthesia ${ }^{2 *}$, Department of Anaesthesiology, Ganga Medical Centre \\ and Hospitals Pvt Ltd, Coimbatore, Tamil Nadu, India. Associate Professor ${ }^{3}$, RUHS College of Medical \\ Science, Jaipur, Rajasthan, India.
}

\begin{abstract}
Craniosynostosis is a type of craniofacial malformation because of premature fusion of cranial suture. The primary treatment is surgical correction which is usually done in stages over years to get best possible outcome. We did a retrospective analysis of five years from $1^{\text {st }}$ August 2011 to $30^{\text {th }}$ July 2016 in which we included twelve patients of craniosynostosis requiring corrective surgeries under general anaesthesia in our institution.
\end{abstract}

Keywords: Craniosynostosis; general anaesthesia; reconstructive surgery; blood loss; syndromic child

\section{Introduction}

Craniosynostosis is the premature fusion of one or more cranial sutures, resulting in an abnormal shape of head either from a primary defect of ossification (primary craniosynostosis) or as part of other syndromes (secondary craniosynostosis). It may be simple or single suture synostosis (only one suture) and complex or compound or multiple synostosis or craniosynostosis (more than one suture). Though craniosynostosis is a fairly prevalent disorder (1 per 2000 live births), syndromic craniosynostosis (SC, with other body deformities or systemic involvements) are relatively rare. The commonly associated syndromes include Crouzon, Apert and Pfeiffer, Saethre-Chotzen and Muenke syndromes with incidence of 1 in 25,$000 ; 1$ in 100,$000 ; 1$ in 100,$000 ; 1$ in 25,000 to 50,000 and 1 in 10,000 live births respectively. ${ }^{1}$

The management of children with craniosynostosis is a multidisciplinary team approach. Providing anaesthesia for these patients presents unique challenges in terms of difficult airway, blood loss,

*Correspondence: Tuhin Mistry

E mail: dr.tuhin2014@gmail.com

https://orcid.org/0000-0003-1904-4831

Received: 08/09/2018

Accepted:24/12/2018

DOI: http:/doi.org/10.4038/slja.v27i1.8378

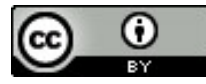

prolonged anaesthesia in paediatrics, syndromespecific issues, metabolic disturbance and postoperative complications.

\section{Case histories}

We did a retrospective review of all the craniosynostosis cases done within five years (from 1st August 2011 to 30th July 2016) at a tertiary care center (Department of Anaesthesiology, S.M.S. Medical College, Jaipur, Rajasthan, India). We included twelve patients of craniosynostosis requiring corrective surgeries under general anaesthesia. Case specific presentation, examination findings and investigations in our patients are described in Table 1.

\section{Discussion}

Corrective surgeries involve craniofacial reconstruction to separate the fused bones which is mostly started in early childhood and performed in stages over years. Pre-anesthesia checkup (PAC) is undoubtedly an extremely important part of the anesthetic care for cranial vault surgery in patients with SC. Babies with craniosynostosis, particularly in case of fusion of multiple sutures or SC may develop increased intracranial pressure as their skulls don't expand enough to make room for growing brains which may lead to various manifestations including visual difficulties even blindness, nausea and vomiting, somnolence, headaches, seizures, brain damage and death in rare instances. ${ }^{2}$ 
Mistry et al. Sri Lankan Journal of Anaesthesiology: 27(1):89-93(2019)

Table 1: Case-based presentation and management of patients

\begin{tabular}{|c|c|c|c|c|c|}
\hline Age/Sex & History & Examination and Investigations & $\begin{array}{l}\text { Associated } \\
\text { syndrome }\end{array}$ & Surgery & $\begin{array}{l}\text { Postoperative } \\
\text { period }\end{array}$ \\
\hline $\begin{array}{l}14 y r s \\
\text { male }\end{array}$ & $\begin{array}{l}\text { reflux of food into nasal cavity, } \\
\text { unable to close the eyes } \\
\text { completely, abnormal shape } \\
\text { of head and face since birth }\end{array}$ & $\begin{array}{l}\text { B/L proptosis, Hypertelorism and } \\
\text { fused fingers of both hands (Type III } \\
\text { syndactyly). systemic examination, } \\
\text { blood investigations, Chest X-ray, } \\
\text { ECG and } 2 D \text { echo findings were } \\
\text { within normal limits }\end{array}$ & $\begin{array}{l}\text { Apert } \\
\text { Syndrome }\end{array}$ & $\begin{array}{l}\text { cranial vault } \\
\text { remodelling with } \\
\text { fronto-orbital } \\
\text { advancement }\end{array}$ & $\begin{array}{l}\text { satisfactory } \\
\text { recovery } \\
\text { discharged } \\
\text { after } 7 \text { days }\end{array}$ \\
\hline $\begin{array}{l}19 y r s \\
\text { male }\end{array}$ & $\begin{array}{l}\text { swelling at root of nose since } \\
\text { birth which was gradually } \\
\text { increasing in size and } \\
\text { increase distance between } \\
\text { the eyes. The mass increases } \\
\text { in size during coughing }\end{array}$ & $\begin{array}{l}\text { no other physical or mental } \\
\text { abnormalities on clinical } \\
\text { examination. } \\
\text { CT scan findings revealed cystic } \\
\text { lesion on right side of nose with a } \\
\text { skull defect at floor of anterior } \\
\text { cranial fossa at cribriform plate of } \\
\text { the ethmoid on right side lateral to } \\
\text { the nasal septum }\end{array}$ & - & $\begin{array}{l}\text { Craniotomy with } \\
\text { excision of sac } \\
\text { and box } \\
\text { osteotomy for } \\
\text { hypertelorism } \\
\text { correction }\end{array}$ & $\begin{array}{l}\text { Uneventful, } \\
\text { discharged } \\
\text { after } 8 \text { days }\end{array}$ \\
\hline 1yr male & $\begin{array}{l}\text { deformity of head and face, } \\
\text { both upper and lower limbs } \\
\text { (fused fingers and toes) since } \\
\text { birth with delayed } \\
\text { developmental milestones, } \\
\text { h/o upper and lower } \\
\text { respiratory tract infection }\end{array}$ & $\begin{array}{l}\text { craniosynostosis of coronal suture, } \\
\text { open anterior and posterior } \\
\text { fontanelle, gaping of sagittal suture, } \\
\text { frontal bossing/L parietal eminence } \\
\text { exaggerated. Increased nasofrontal } \\
\text { angle, hypertelorism, B/L proptosis, } \\
\text { hypoplasia of mid face, high arched } \\
\text { palate with cleft palate, B/L } \\
\text { syndactyly of hands (fused } \\
2^{\text {nd }}, 3^{\text {rd }}, 4^{\text {th }} \& 5^{\text {th }} \text { digits), B/L fused } \\
\text { toes. USG brain \& 2D } \\
\text { echocardiography were within } \\
\text { normal limits }\end{array}$ & $\begin{array}{l}\text { Apert } \\
\text { Syndrome }\end{array}$ & $\begin{array}{l}\text { craniotomy with } \\
\text { fronto-orbital } \\
\text { advancement }\end{array}$ & $\begin{array}{l}\text { Uneventful, } \\
\text { discharged } \\
\text { after } 7 \text { days. }\end{array}$ \\
\hline $\begin{array}{l}13 y r s \\
\text { female }\end{array}$ & $\begin{array}{l}\text { swelling over left forehead } \\
\text { and bulging of left eyeball } \\
\text { which started and gradually } \\
\text { increased over } 1 \text { year with no } \\
\text { history of headache, vomiting } \\
\text { and seizure. She underwent } \\
\text { percutaneous balloon } \\
\text { pulmonary valvuloplasty for } \\
\text { valvular stenosis } 11 \text { years } \\
\text { back }\end{array}$ & $\begin{array}{l}\text { swelling was bony hard, smooth } \\
\text { contoured, round with abnormal } \\
\text { protrusion of left eyeball. } \\
\text { fibrous dysplasia of left frontal bone } \\
\text { and roof of orbit. }\end{array}$ & - & $\begin{array}{l}\text { Deroofing of left } \\
\text { orbit and frontal } \\
\text { bone contouring } \\
\text { were done under } \\
\text { GA }\end{array}$ & $\begin{array}{l}\text { Satisfactory, } \\
\text { discharged } \\
\text { after } 5 \text { days. }\end{array}$ \\
\hline $\begin{array}{l}19 y r s \\
\text { female }\end{array}$ & $\begin{array}{l}\text { Headache, swelling of right } \\
\text { forehead and protrusion of } \\
\text { right eye for } 5 \text { months. } \\
\text { Hypothyroidism for } 2 \text { years } \\
\text { (was on l-thyroxin) and } \\
\text { seizure disorder for } 4 \text { years } \\
\text { (was on levetiracetam, } \\
\text { carbamazepine and } \\
\text { clobazam) }\end{array}$ & $\begin{array}{l}\text { swelling was bony hard, diffuse, } \\
\text { proptosis of right eyeball. } \\
\text { fibrous dysplasia of right frontal } \\
\text { bone and skull base }\end{array}$ & - & $\begin{array}{l}\text { Cranioplasty with } \\
\text { right optic nerve } \\
\text { decompression }\end{array}$ & $\begin{array}{l}\text { Blurring of } \\
\text { vision } 6 \text { hours } \\
\text { after surgery. } \\
\text { Examination } \\
\text { revealed } \\
\text { congested } \\
\text { right eye, no } \\
\text { finger counting } \\
\text { or hand } \\
\text { movement, but } \\
\text { perception of } \\
\text { light and } \\
\text { projection of } \\
\text { rays were } \\
\text { present with } \\
\text { pale optic disc. } \\
\text { she was given } \\
\text { pulse methyl } \\
\text { prednisolone }\end{array}$ \\
\hline
\end{tabular}


Mistry et al. Sri Lankan Journal of Anaesthesiology: 27(1):89-93(2019)

\begin{tabular}{|c|c|c|c|c|c|}
\hline & & & & & $\begin{array}{l}\text { therapy and } \\
\text { moxifloxacin. } \\
\text { stayed } 4 \text { days } \\
\text { in hospital and } \\
\text { discharged. }\end{array}$ \\
\hline $\begin{array}{l}\text { 2yrs } \\
\text { male }\end{array}$ & $\begin{array}{l}\text { swelling over parietal and } \\
\text { occipital region since birth }\end{array}$ & $\begin{array}{l}\text { a soft cystic globular swelling } \\
\text { present over occipital region, } \\
\text { overlying skin is thin, no prominent } \\
\text { vascular markings, positive } \\
\text { transillumination test. He was } \\
\text { diagnosed to have occipital } \\
\text { encephalocele with } \\
\text { craniosynostosis. NCCT and MRI of } \\
\text { brain were suggestive of occipital } \\
\text { encephalocele with herniation of } \\
\text { cerebellar hemisphere. }\end{array}$ & - & $\begin{array}{l}\text { intraop cardiac } \\
\text { arrest } \\
\text { (ventricular } \\
\text { tachycardia } \\
\text { followed by } \\
\text { bradycardia) } \\
\text { which was } \\
\text { revived, and } \\
\text { patient was } \\
\text { shifted to ICU } \\
\text { after surgery }\end{array}$ & $\begin{array}{l}\text { was on } \\
\text { inotropic } \\
\text { support and } \\
\text { mechanical } \\
\text { ventilation } \\
\text { because of } \\
\text { shock and } \\
\text { respiratory } \\
\text { failure. patient } \\
\text { had another } \\
\text { episode of } \\
\text { cardiac arrest } \\
4 \text { hours after } \\
\text { surgery during } \\
\text { ICU stay but } \\
\text { could not be } \\
\text { revived inspite } \\
\text { of all efforts. }\end{array}$ \\
\hline $\begin{array}{l}\text { 22yrs } \\
\text { male }\end{array}$ & $\begin{array}{l}\text { increased distance between } \\
\text { two eyes and depressed } \\
\text { nasal bridge since birth. She } \\
\text { was operated for squint and } \\
\text { nasal dorsal augmentation } \\
\text { with cranial bone graft one } \\
\text { year back. }\end{array}$ & $\begin{array}{l}\text { systemic examination, blood } \\
\text { investigations, Chest } X \text {-ray, ECG } \\
\text { and } 2 D \text { echo findings were within } \\
\text { normal limits }\end{array}$ & - & $\begin{array}{l}\text { Box osteotomy } \\
\text { under GA }\end{array}$ & $\begin{array}{l}\text { satisfactory } \\
\text { recovery. } \\
\text { discharged } \\
\text { after } 7 \text { days }\end{array}$ \\
\hline $\begin{array}{l}11 \mathrm{yrs} \\
\text { female }\end{array}$ & $\begin{array}{l}\text { Operated previously with Le } \\
\text { Forte II advancement }\end{array}$ & $\begin{array}{l}\text { Mid face hypoplasia, class IV } \\
\text { malocclusion \& mid-face hypoplasia }\end{array}$ & $\begin{array}{l}\text { Crouzon's } \\
\text { syndrome }\end{array}$ & $\begin{array}{l}\text { Le Forte III } \\
\text { advancement } \\
\text { osteotomy }\end{array}$ & $\begin{array}{l}\text { Satisfactory, } \\
\text { Discharged } \\
\text { after } 6 \text { days }\end{array}$ \\
\hline $\begin{array}{l}1 \mathrm{yr} \\
\text { female }\end{array}$ & $\begin{array}{l}\text { Deformity of head and face } \\
\text { since birth }\end{array}$ & Asymmetry of the head & & $\begin{array}{l}\text { B/L Fronto-orbital } \\
\text { advancement } \\
\text { with cranial vault } \\
\text { remodelling }\end{array}$ & $\begin{array}{l}\text { Uneventful } \\
\text { discharged } \\
\text { after } 7 \text { days }\end{array}$ \\
\hline $\begin{array}{l}2 y r s \\
\text { female }\end{array}$ & $\begin{array}{l}\text { Increasing head size more } \\
\text { than normal since birth, past } \\
\text { history: right parietal burr hole } \\
\text { with ventricular tap done } 2 \\
\text { months back but as the CSF } \\
\text { pressure was very low, VP } \\
\text { Shunt was not done }\end{array}$ & $\begin{array}{l}\text { Increase circumference of head } \\
\text { with prominent forehead, sunset } \\
\text { sign in both eyes(hydrocephalus) }\end{array}$ & $\begin{array}{l}\text { Craniosynos } \\
\text { tosis with } \\
\text { aqueductal } \\
\text { stenosis } \\
\text { with type I } \\
\text { Arnold } \\
\text { Chiari } \\
\text { malformatio } \\
n\end{array}$ & $\begin{array}{l}\text { Fronto-temporo- } \\
\text { parietal } \\
\text { remodelling }\end{array}$ & $\begin{array}{l}\text { After the } \\
\text { surgery, } \\
\text { patient was } \\
\text { shifted to ICU } \\
\text { under } \\
\text { antibiotics, } \\
\text { steroid and } \\
\text { anticonvulsant. } \\
\text { On the second } \\
\text { post-operative } \\
\text { day she had } \\
\text { one episode of } \\
\text { seizure } \\
\text { following which } \\
\text { she went into } \\
\text { asystole. } \\
\text { CPCR started }\end{array}$ \\
\hline
\end{tabular}




\begin{tabular}{|l|l|l|l|l|l|}
\hline & & & & & $\begin{array}{l}\text { and revived } \\
\text { but inspite of } \\
\text { all efforts she } \\
\text { passed away } \\
\text { on 3rd } \\
\text { post- } \\
\text { operative day. }\end{array}$ \\
\hline $\begin{array}{l}\text { 8yrs } \\
\text { male }\end{array}$ & $\begin{array}{l}\text { Asymmetric growth of skull } \\
\text { and abnormal appearance of } \\
\text { both eyes which gradually } \\
\text { became apparent after birth }\end{array}$ & $\begin{array}{l}\text { B/L proptosis, NCCT \& CECT brain } \\
\text { revealed type I Arnold Chiari } \\
\text { malformation and luckenschaden } \\
\text { skull }\end{array}$ & $\begin{array}{l}\text { Crouzon's } \\
\text { syndrome }\end{array}$ & $\begin{array}{l}\text { B/L fronto orbital } \\
\text { advancement } \\
\text { with Le Forte III }\end{array}$ & $\begin{array}{l}\text { Uneventful } \\
\text { discharged } \\
\text { after } 9 \text { days }\end{array}$ \\
\hline $\begin{array}{l}\text { 18yrs } \\
\text { female }\end{array}$ & $\begin{array}{l}\text { Increased distance between } \\
\text { eyes since birth, difficulty in } \\
\text { learning and decreased } \\
\text { performance in school }\end{array}$ & $\begin{array}{l}\text { Distance between the medial canthi } \\
\text { was } 35 \text { mm }\end{array}$ & - & $\begin{array}{l}\text { box osteotomy, } \\
\text { medialisation of } \\
\text { orbit and dorsal } \\
\text { nasal } \\
\text { augmentation } \\
\text { with bone graft }\end{array}$ & $\begin{array}{l}\text { Satisfactory, } \\
\text { discharged } \\
\text { after } 8 \text { days }\end{array}$ \\
\hline
\end{tabular}

Airway should be assessed thoroughly during PAC as most of the patients are in paediatric age. Cartilaginous abnormalities of the trachea, fusion of the cervical vertebrae, tracheal stenosis and angular deviation of the trachea contribute to respiratory morbidity or difficult intubation in $\mathrm{SC}^{3}$ In addition, presence of wheeze and obstructive sleep apnoea complicates the scenario. We should be prepared with difficult airway cart to manage loss of airway patency, risk of difficult intubation and respiratory complications during general anaesthesia. In our $3^{\text {rd }}$ case, patient had respiratory infection due to the underlying condition and increased secretions.

SC, including Apert's syndrome, can have associated atrial septal defect, ventricular septal defect or patent ductus arteriosus. ${ }^{4}$ Our $4^{\text {th }}$ case of craniosynostosis was associated with pulmonary stenosis for which she underwent percutaneous balloon pulmonary valvuloplasty 11 years back.

Laboratory evaluation usually includes a complete blood count, coagulation studies, liver and renal function tests, blood sugar, electrolytes, chest $\mathrm{x}$ ray, ECG, type and cross match for adequate volumes of packed red blood cells. A written and informed consent as well as high risk consent should be taken from parents after full explanation about the intraoperative complications, blood transfusion, possibility of post-operative stay in intensive care unit (ICU) and mechanical ventilation.

The anaesthesiologist must be ready for airway problems, intubation difficulties, blood loss and massive blood transfusion, perioperative haemodynamic changes, disseminated intravascular coagulation, venous air embolism, positional injury, hypothermia and even the problems which may arise from different systemic involvements in SC. Monitoring should include pulse oximeter, non-invasive blood pressure, electrocardiograph, end tidal $\mathrm{CO}_{2}$, airway gases and pressures as per American Society of Anesthesiologists guidelines as well as advanced monitoring like arterial blood pressure, central venous pressure (CVP), temperature, urine output etc. Point-of-care testing for haematocrit, electrolytes and acid-base balance is highly desirable. Adequate venous access preferably with two large bore cannula is mandatory. For paediatric age group 24 to 20 -gauge cannulae were appropriate in our patients. Central access and CVP monitoring is not routinely practiced by us but is used if adequate peripheral access cannot be obtained and in case of huge blood loss or to manage venous air embolism (VAE). VAE as a complication is reported with incidence ranging from $2.6 \%$ to $82.6 \%$ as detected by precordial Doppler monitoring or echocardiography. ${ }^{5}$

We used intravenous atropine or glycopyrrolate and fentanyl as premedication. Induction usually carried out by either intravenous induction agent like thiopentone, etomidate or inhalation agent sevoflurane. We use succinylcholine or rocuronium for laryngoscopy and intubation and for maintenance we preferred atracurium or vecuronium and sevoflurane. In presence of increased intracranial pressure, high dose sedative premedication, ketamine, and succinylcholine was avoided.

We used $0.9 \%$ saline and lactated ringer's solution for maintenance, to replace the volume loss and to 
Mistry et al. Sri Lankan Journal of Anaesthesiology: 27(1):89-93(2019)

replace a portion of the blood loss. Colloids and inotropes were used as per requirements. An accurate determination of ongoing blood loss during surgery and a precise restoration of that represent one of the major concerns. Blood saving begins with evaluation of the patient's bleeding risk, type, technique and length of surgery, number of cranial sutures involved and patients age, weight and physical status. Blood should be in the operating room before surgery begins as estimated blood volume (EBV) is limited to $80 \mathrm{ml} / \mathrm{kg}$. Common sources of blood loss are the subgaleal tissues, fresh ends of the cut bones and dural venous sinuses. After osteotomy, blood loss is usually slow and continuous. It may be impossible to accurately measure blood loss, as much of the loss is absorbed by and/or under the drapes, surgical gowns, on sponges and in suction tubing and reservoirs mixed with saline irrigation. It is best advised to start transfusion at the start of skin incision and to keep up with the ongoing losses. We also transfused fresh frozen plasma and platelets for correction of microvascular bleeding in the setting of massive transfusion when coagulation tests could not be obtained in a timely manner.

During craniosynostosis surgery a large surface area is exposed to the atmosphere, which may result in excessive heat loss. We monitored core as well as peripheral temperature intraoperatively and normothermia was maintained by covering the body with cotton roll, using warm intravenous fluids and convective forced-air warming devices. Post-operative care should be provided in postoperative anaesthesia care unit or ICU because of lengthy surgery, unstable haemodynamics, elective ventilation and good nursing care. Out of the 12 cases described, 10 patients were discharged after successful recovery, but one patient (case 6, Table1) had arrhythmia and one patient (case 10, Table 1) developed seizures in the post-operative period. Appropriate antibiotics, anticonvulsant, good analgesics and maintenance of haematocrit level are the mainstays of postoperative care.

\section{Conclusion}

Management of craniosynostosis is challenging for an anaesthesiologist in view of paediatric patients with difficult airway, prolonged duration of surgery, high likelihood of significant blood loss, massive blood transfusions and post-operative complications. With proper planning, intraoperative vigilance, and postoperative care, patient outcome is satisfactory.

\section{References}

1. Derderian C, Seaward J. Syndromic Craniosynostosis. Seminars in Plastic Surgery. 2012;26(2):64-75. https://doi.org/10.1055/s-0032-1320064 PMid:23633933 PMCid:PMC3424695

2. Faberowski LW, Black S, Mickle JP. Craniosynostosis: an overview. Am J Anesthesiol 2000;27(2):76-82.

3. Morris GP, Cooper MG. Difficult tracheal intubation following midface distraction surgery. PediatrAnaesth 2000; 10: 99-102. https://doi.org/10.1046/j.14609592.2000.00466.x

4. Breugem CC, Fitzpatrick DF, Verchere C. Monozygotic twins with Apert syndrome. Cleft palate craniofac J 2008;45:101-104. https://doi.org/10.1597/06-149.1 PMid:18215098

5. Faberowksi LW, Black S, Mickle JP. Incidence of venous air embolism during craniectomy for craniosynostosis repair. Anesthesiology 2000;92:20-3. https://doi.org/10.1097/00000542-200001000$\underline{00009}$ 